\title{
FAKTOR-FAKTOR YANG MEMPENGARUHI ENVIRONMENTAL DISCLOSURE PADA PERUSAHAAN MANUFAKTUR DI SINGAPORE EXCHANGE (SGX)
}

\author{
Nilam Putri ${ }^{1) *}$ Indah Fajarini Sri Wahyuningrum ${ }^{2)}$ \\ ${ }^{1,2)}$ Akuntansi, Universitas Negeri Semarang \\ Email: nilamputri01.np@gmail.com
}

Diterima 30 November 2020 / Disetujui 25 Februari 2021

\begin{abstract}
This study aims to examine the effect of industry type, company tze, ten auditor type, women directors, and managerial ownership on environmental do sure. En onmental disclosure is measured using content analysis to determine the quantity of isclos. The pop ation of this study are manufactur companies listed in the Singapore Exchange $(S, X)$ during periog of 2017 2018. Purposive sampling is used as a sampling method, there are 61 upanie as the rea sample and 122 units of analysis to be used in this study. Multiple linear recess ar aysis mas y to test the effect between variables. The data analysis technique used descr tive statis, lanalys techniques and inferential statistical analysis techniques. The research sho ed hat compa siz has a significant positive effect on environmental disclosure. Similar resubs ye for in the le age and the type of auditor who find a significant positive effect on envirg meml disclos Meanwhile, type of industry, women directors and managerial ownership do not ho e a significant effec y environmental disclosure. Based on the research results, the selection of bi four KAP as a company auditor can improve environmental disclosure reporting, this is because th uality of the audited report has high credibility and requires companies to be able to reporenvironme disclos re in their business reports. Large companies get more attention by the public $\mathrm{se}$ of the ility and reputation. Environmental disclosure is one way to maintain company cred bili

Keywords: Content Analysis, Eny ronm tal Disc sure, Leverage, Singapore Exchange

ABSTRAK: Penelitian ini tipe auditor, women ctors, da kepemman manajerial terhadap environmental disclosure. Pengukuran environn nta isclosure nggunakan content analysis untuk mengetahui banyaknya kuantitas pengung pan Pene in ini me,gambil populasi pada perusahaan manufaktur di Singapore Exchange (SGX ahun 2017-20 Purposive sampling digunakan sebagai metode pengambilan sampel, sebanyak 61/ unsahad sampel d Toleh sehingga menghasilkan total 122 unit analisis yang akan digunakan dalam v itian. Analisis regresi linier berganda digunakan untuk menguji pengaruh antar variabel - knik an is data henggunakan statistik deskriptif dan teknik analisis statistik inferensial. Tem n pe litian mo bul akan bahwa ukuran perusahaan berpengaruh positif signifikan terhadap enviro ventd disclosury Hasil yang serupa terdapat pada variabel leverage dan tipe auditor yang menemu paro ositif signifikan terhadap environmental disclosure. Sementara itu, tipe industri, women dir $r$ rs dan kepemilikan manajerial tidak berpengaruh signifikan terhadap environmental disclosure. Be arkan hasil penelitian, pemilihan KAP big four sebagai auditor perusahaan dapat meningkatkan belaporan environmental disclosure, hal ini dikarenakan kualitas laporan yang diaudit memiliki kredibilitas tinggi dan mengharuskan perusahaan untuk dapat melaporkan environmental disclosure dalam laporan bisnisnya. Perusahaan besar lebih mendapat perhatian oleh masyarakat karena kredibilitas dan reputasinya. Pengungkapan lingkungan merupakan salah satu cara untuk mempertahankan kredibilitas perusahaan.
\end{abstract}

Kata Kunci: Content Analysis, Environmental Disclosure, Leverage, Singapore Exchange. 


\section{Pendahuluan}

Seiring dengan perkembangan ilmu dan teknologi, tingkat kesadaran akan lingkungan kian mulai meningkat di berbagai negara. Perusahaan memiliki fungsi yang substansial dalam rangka meningkatkan kesadaran terhadap lingkungan. Pihak yang berwenang dalam hal ini stakeholders juga bertanggung jawab atas keadaan kualitas lingkungan (Dyduch, 2017). Salah satu upaya untuk mengurangi masalah lingkungan dengan melakukan environmental disclosure. Pengungkapan yang dilakukan perusahaan mengenai operasi dan aktivitas mereka secara terbuka dan nyata dapat meningkatkan tanggung jawab sosial dan lingkungan di masyarakat berdasarkan tempat mereka beroperasi (Benlemlih et al., 2018).

Environmental disclosure yang dilaporkan pada annual statement akan memungkinkan pihak tertentu untuk memperoleh informasi yang diperlukan o membantu pengambilan keputusan di mas mendatang (Ningtyas \& Triyanto, 2019). Perusahaan yang 1 ito orkan environmental disclosure $\mathrm{Ym}$ poran bisnisnya akan meningk ... an investor untuk men amkan h dalnya sebagai dukungan $\mathrm{ke}$ $\mathrm{da}$ perus man karena telah Angungka on aktiritas kegiatan terha ap lizgkungan. vestor dan masyarakat o, any? tidak teryurik pada perusahaan ya dapt merugikan lingk ıgas Oleh rena itu, diperlukan keter kaan informas ingkungan untuk menun o ar haogmana perusahaan menyelesat on dan menangani masalah tersebut (De \& Yasa, 2017). Informasi pengungkapar lingkungan umumnya dialporkan dalam sustainability report baik dilaporkan pada annual report atau di laporkan dalam laporan terpisah.

Pelaporan sustainability report dalam laporan perusahaan di sejumlah negara masih bersifat sukarela (voluntary), tetapi terdapat sejumlah negara yang sudah menerapkan mandatory disclosure, salah satunya yaitu Singapura. Pada tahun 2011, Singapore Exchange (SGX) semula menerapkan kebijakan untuk melaporkan sustainability report secara sukarela pada perusahaan yang tercatat. Namun, pada tahun 2016, SGX menerbitkan kebijakan mandatory disclosure. Kebijakan ini mulai berlaku pada periode laporan yang berakhir pada 31 Desember 2017 atau setelahnya. Lebih lanjut, aturan tersebut tertuang pada Practice Note 7.8: Sustainability Reporting Guide and Practice Note $\mathbf{S u s t a i n a b i l i t y}$ Reporting Guide (S ngaporo Exchange, 2016).

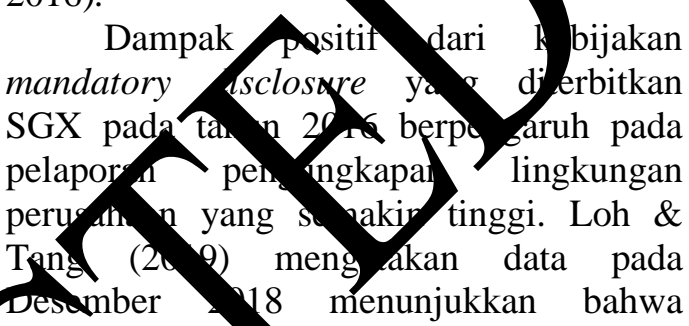
terdapat 495 pe ahaan yang melaporkan sustainability report, sebanyak $80 \%$ verupakan perusahaan yang melaporkan S. vinabi ity report untuk pertama kalinya. Dari jumlah 495 perusahaan, sebanyak 201 - masahaan melaporkan sustainability report dalam annual report dan sisanya 294 perusahaan melaporkan sustainability report dalam laporan terpisah.

Komponen material yang terdapat dalam sustainability report yaitu material environmental, social and governance (ESG). Material environmental menduduki peringkat kedua setelah material social. Selain itu, dari 8 topik environmental yang mengacu pada GRI Standard 2016, hanya 3 topik yang terdiri dari (energy, effluents \& waste dan water) yang banyak diungkapkan oleh perusahaan. Sedangkan, topik environmental lainnya masih menduduki peringkat terbawah (Loh \& Tang, 2019).

Penelitian terkait pengungkapan SR di negara-negara ASEAN (Indonesia, Filipina, Malaysia, Singapura dan Thailand) yang dilakukan oleh Loh \& Thomas (2018) menyatakan bahwa Singapura menduduki peringkat ke-2 setelah Malaysia dengan nilai $61.7 \%$. Hasil ini menunjukkan bahwa tingkat pengungkapan SR di Singapura cukup tinggi. Namun, hal ini tidak menjamin bahwa Singapura terbebas dari masalah lingkungan. Salah satu contoh 
kasus lingkungan yaitu terkait dengan pembuangan limbah secara ilegal yang dilakukan beberapa perusahaan. Public Utilities Board (PUB) menyatakan bahwa pelanggaran ditemukan pada 38 perusahaan dengan total denda secara keseluruhan mencapai S\$ 253.700 selama bulan Juni 2018 hingga Mei 2019. Diantara 38 perusahaan, 18 perusahaan merupakan pelanggar berulang. Salah satu perusahaan tersebut merupakan perusahaan roti ternama Breadtalk Pte. Ltd yang dikenakan sanksi berupa denda sebesar S\$16.300 oleh PUB akibat pelanggaran ganda untuk pemakaian bahan kimia yang diatur melebihi batas yang diizinkan ke saluran pembuangan umum pada 2 Januari hingga 20 April 2017 (PUB, 2019). Berdasarkan pernyataan tersebut membuktikan bahwa masih rendahnya tingkat kesadaran lingkungan pada perusahaan.

Peran penting dari sejumlah otoritas dan pemangku kepentingan menjadi faktor yang dapat mempengaruhi pengungkapan lingkungan. Tanpa ukuran dewan ya tepat dan keragaman gender dewan sebaga struktur corprorate governance yang kuat, stabil, tidak bias dan beragam on maka pelaporan environmenta dis osure dianggap masih kurang Acro 0 (120) Struktur corporate vernance dalam perusahaan juga apa mempens whi pengungkapan ingkunga Corp rate governance m upakan suatu s. ktur untuk pengambilan putu perusal,an yang transparan, adil, pat woktu dan tegas berda arka perhat terb dap kebutuhan serka erspe tif peme $1 \mathrm{~g}$ saham beserta konsum komunitas lokal (TSE, 20

Salah bagian dari corporate governance ytitu struktur dewan. Menurut laporan Singapore's Council for Board Diversity (CBD) mengatakan bahwa women directors yang berada pada 100 perusahaan ternama di Singapura mencapai $16,2 \%$ pada akhir 2019, angka tersebut meningkat $1 \%$ dari tahun sebelumnya (CBD, 2020). Oleh karena demikian, terdapat peningkatan yang signifikan terhadap partisipasi direktur perempuan dalam perusahaan. Keberadaan women directors dalam struktur dewan dapat memberikan pengaruh positif. Semakin banyak dewan direksi yang terdapat dalam struktur dewan maka keputusan yang diambil akan jauh lebih baik. Selain women directors, manajer perusahaan juga menjadi faktor yang mampu meningkatkan pengungkapan lingkungan. Manajer yang memiliki saham perusahaan memiliki hak yang sama dengan pemegang saham lainnya. Hal ini memberikan tanggung jawab yang lebih terhadap peran dari manajer. Peran manajer corogai pemegang saham memberikan keuntur. khusus berkaitan dengan Tra CSR (S i et al., 2018). Keikutser ma jer dalai jajaran pemegang salam berpenga b pa a setiap keputusan an diam $\mathbf{X}$

F cror nnya yang dapat mem o aruhi peh ngk pan lingkungan yait kara ristik pert. naan. Karakteristik perwahaan d taranya seperti tipe industri, ukuran perusa 1 , leverage, dan tipe auditor. Tahun 2018, SGX bekerjasama lengan Ndtional University of Singapore 1 ilis Sy tainability Reporting - Progress and Challenges menggunakan Global dustry Classification Standard (GICS) søagai standar untuk mengklasifikasi sektor industri (Loh \& Tang, 2019). Tipe industri terbagi menjadi industri high profile dan low profile. Industri high profile memiliki risiko yang tinggi dibandingkan low profile karena proses produksinya berdampak pada lingkungan.

Suatu perusahaan dikatakan besar jika dipandang dari sisi nilai aset perusahaan tersebut. Semakin besar ukuran perusahaan maka semakin tinggi pula perhatian masyarakat. Hal ini memberikan tekanan pada perusahaan untuk memberikan keterbukaan informasi, salah satunya mengenai environmental disclosure. Welbeck et al., (2017) membuktikan dalam penelitiannya bahwa ukuran perusahaan yang besar lebih banyak melaporkan pengungkapan informasi linkungan daripada perusahaan dengan ukuran kecil. Leverage merupakan kemampuan perusahaan untuk memenuhi kewajiban jangka panjang. Rasio leverage yang tinggi tentu memberikan risiko yang dapat mempengaruhi keputusan perusahaan. Salah satunya keputusan mengenai 
environmental disclosure. Meskipun demikian, tidak sedikit perusahaan yang masih melaporkan informasi lingkungan pada sustainability report. Perusahaan penghasil polusi akan melaporkan lebih banyak informasi lingkungan meskipun mereka memiliki kewajiban yang tinggi (Omoye \& Wilson-Oshilim, 2018). Auditor mendukung perusahaan untuk melaporkan informasi lingkungan pada laporan tahunannya (Welbeck et al., 2017). Pelaporan environmental disclosure dapat dipengaruhi oleh pemilihan jasa Kantor Akuntan Publik (KAP).

Berdasarkan latar belakang penelitian ini, diketahui bahwa terdapat peningkatan pengungkapan sustainability report, tetapi tidak sejalan dengan rendahnya item environmental disclosure yang dilaporkan. Permasalahan lingkungan yang terjadi memberikan bukti bahwa tingkat kepatuhan perusahaan terhadap suatu kebijakan masih rendah. Penelitian ini bertujuan yaitu berfokus untuk mengetahui faktor-faktor yang terdiri dari tipe industri, ukui perusahaan, leverage, tipe audito corporate governance (kepemilikan manajerial dan women dire yang dapat memberikan pengaruh da pe, poran environmental disclosure Sins w

\section{Pengembangan Hir tes,}

Teori legit ast berm dari se ouah rancangan gitimasi organ esi yang diartikan sepo stat atau ko disi yang timbul pada saa lai per sahaan sejalan terhar ap arnya iai ssial dari suatu sister nila di ma entitas menjadi bagiann, \& Kassan, 2015). Tasya \& Cheis vanny (2019) menyatakan legitimasi dasarkan dari fenomena kontrak sosial di antara perusahaan dengan masyarakat, memiliki tujuan yang sama dengan nilai-nilai pada masyarakat, apabila terjadi ketidakharmonisan antara perusahaan dengan masyarakat (legitimacy gap) maka perusahaan akan kehilangan legitimasinya, yang kemudian dapat membawa pengaruh negatif bagi kontinuitas perusahaan. Oleh karena itu, perusahaan harus beroperasi sesuai dengan norma dan harapan masyarakat sehingga keberadaanya dapat diterima secara hukum
(Lu \& Taylor, 2018). Informasi yang diungkapkan diikuti dengan langkah yang nyata sejalan dengan nilai sosial dan norma yang ada sebagai perwujudannya. Legitimasi yang bersifat abstrak akan sulit memotivasi organisasi untuk melakukan environmental disclosure secara sukarela (Schiopoiu \& Popa, 2013).

Pengungkapan sustainability report merupakan bentuk pertanggungjawaban terhadap masalah sosial dan lingkungan. Pengungkapan lingkungan- $\mathrm{k}_{\mathrm{k}}$ n berdampak pada pengambilan kepur on yang dilakukan stakehcra s, karen tingkat pengungkapan fong h gi ber ngaruh juga pada ti gginy ting kep rcayaan stakeholders hada nerusa 1. Ghozali \& Char 1800 ) erpenda bat terkait teori stake o ver diartik ba wa perusahaan bukap or nisasi ya memprioritaskan repentingan udiri, akan tetapi juga dapat memberikan ko yungan bagi pemangku kepentingap. Perusahaan membutuhkan ukungan stakeholder, karena kegiatan ba dijalankan atas dasar persetujuan dari stakeholder. Peran voholder akan menyebabkan perusahaan mendapat tekanan untuk melaporkan informasi lingkungan, sehingga dengan adanya keterbukaan informasi diharapkan stakeholders dapat mendukung kegiatan perusahaan (Hadiningtyas \& Mahmud, 2017).

Teori agensi mengungkapkan bahwa terdapat dua pihak kepentingan. Pihak kepentingan tersebut diantaranya dari pihak agen (manajemen) dan pihak prinsipal (pemegang saham). Salah satu bentuk pertanggungjawaban perusahaan terhadap dua pihak tersebut dengan memanfaatkan sistem tata kelola perusahaan (corporate governance) (Solikhah \& Winarsih, 2015). Pengambilan keputusan bisnis diwakilkan kepada manajer selaku agen oleh pihak prinsipal yaitu pemegang saham. Keputusan yang dibuat oleh manajer tidak selalu memenuhi kepentingan pemegang saham. Sedangkan, manajer memiliki tujuan pribadi pada setiap pengambilan keputusan, disamping tujuan untuk memenuhi kepentingan pemegang saham. Pengungkapan lingkungan menjadi salah satu cara bagi manajemen untuk 
menunjukkan perilaku oportunistik yang dapat merugikan pemilik perusahaan, selain itu pengungkapan informasi lingkungan tunduk pada kebijakan manajemen administratif, tetapi tidak sepenuhnya terbebas dari aturan otoritas (Oserogho, 2020) . Oleh karena itu, konflik kepentingan agen dan prinsipal sering terjadi. Ketidakselarasan informasi merupakan penyebab adanya konflik kepentingan, ketidakselarasan terjadi disebabakan pihak manajer memiliki lebih banyak informasi dibandingan shareholders.

Feminist ethical theory memfokuskan pada keterkaitan (sosialis) dalam penyelesaian tugas tertentu. Berbanding terbalik dari sudut pandang masculinist yang memfokuskan hak dan kewajiban secara perorangan terhadap tugas tertentu (Wicks et al., 1994). Keberadaan dewan wanita dalam struktur dewan memberikan suasana kerja yang lebih baik, terlihat dari kemampuan bersosialisasi dewan wanita yang lebih baik daripa dewan laki-laki. Kehadiran dewan wanit juga menunjukkan meningkatnya keragaman dalam perspektif an 20 dewan yang mampu mempengarub venga bilan keputusan perusahaan. Nh re itu kehadiran dewan wanita akan meningkatkan pel ora environ ntal disclosure di pery han.

Pengaruh Th Indus i Terhadd

Environmental \$ closure

oed pa studi terdahulu mero gka an bal jenis industri digolon perusahaan high profile da. low profile. Besar kecilnya tingkat sens vis perusahaan terhadap lingkungan betgantung pada jenis-jenis tipe industri. Perusahaan high profile akan lebih mematuhi aturan untuk mengungkapkan lebih banyak indikator pengungkapan environmental dislcosure sesuai dengan aturan yang berlaku. Al-Qahtani \& Elgharbawy (2020) dalam penelitiannya menemukan bahwa perusahaan di sektor padat karbon lebih patuh pada peraturan karena kecenderungan perusahaan untuk mencemari lingkungan lebih tinggi. Jenis perusahaan high profile rentan menjadi sorotan publik dancenderung memiliki cakupan risiko yang lebih besar menyangkut persoalan lingkungan. Berdasarkan teori stakeholder yang menjelaskan sebagian besar industri yang diklasifikasikan sebagai high profile memperoleh tuntutan yang berasal dari masyarakat dan pemangku kebijakan (Nugraha \& Juliarto, 2015). Tekanan sosial dari berbagai pihak akan mendorong perusahaan untuk melaporkan informasi pengungkapan lingkungan-Penjelasan di atas selaras dengan udi yar dilakukan Burgwal \& Vieira 214) Oht a et al. (2016) dan We ack \& ol., (20 ) yang membuktikan bahya ter vat engaruh positif artan tip indu dengan environ ental sclosur Sedangkan Khal $A$ al. $(20>m$ nemukan tidak tera.pat p garuh ya signifikan antara upo indut dengan environmental disclosure.

H1: Tipe industr memiliki pengaruh positif ignifikan terhadap environmental c. losur

\section{vogaruh Ukuran Perusahaan Terhadap \\ Euvironmental Disclosure}

Ukuran perusahaan dapat dihitung menggunakan log total aktiva. Besarnya ukuran perusahaan, akan meningkatkan intensitas aktivitas usaha. Hal ini dikarenakan sumber daya keuangan yang banyak, manajemen dan staf teknik yang memiliki kualifikasi tinggi akan memudahkan penerapan pengungkapan lingkungan untuk mematuhi persyaratan dari pemerintah dan masyarakat (Nguyen et al., 2020). Teori legitimasi menunjukkan bahwa perusahaan besar akan merespon lebih terkait environmental disclosure. Hal ini dikarenakan aktivitas perusahaan yang berdampak pada ekosistem lingkungan. Ikatan yang baik antara perusahaan dan masyarakat akan tercipta jika semua pihak turut bekerja sama. Perusahaan ukuran besar mendapatkan pengawasan lebih karena tanggungjawabnya terhadap lingkungan. Penelitian oleh Solikhah \& Winarsih (2015), Welbeck et al., (2017), Wahyuningrum \& Budihardjo (2018) dan Baalouch et al. (2019) membuktikan bahwa terdapat pengaruh positif antara ukuran 
perusahaan terhadap environmental disclosure. Ukuran perusahaan berpengaruh negatif ditemukan oleh Dibia \& Onwuchekwa, (2015).

$\mathrm{H} 2$ : Ukuran perusahaan memiliki pengaruh positif signifikan terhadap environmental disclosure

\section{Pengaruh Leverage Perusahaan Terhadap Environmental Disclosure}

Leverage merupakan kemampuan perusahaan dalam memenuhi kewajiban. Salah satu metode pengukuran leverage yaitu DER (Debt to Equity Ratio). Omoye \& Oshilim (2018) menyatakan bahwa para investor dan pemberi pinjaman hanya bergantung pada laporan keuangan untuk mengevaluasi status keuangan perusahaan. Tingkat leverage yang tinggi memungkinkan perusahaan untuk mengungkapkan environmental disclosure yang tinggi. Pengungkapan informasi lingkungan memberikan respon positif dari para stakeholder meskipun tingkat leverage tinggi. Perusahaan memilih untuk te melakukan pengungkapan lingkunga sebagai bentuk tanggungjawab terhadap para stakeholder. Penelitian ol nto \& Muzzammil (2016) dan Hie t al., 2019) menemukan pengaruh psiti vace terhadap environment disclosu Salan satu strategi perusal an uk memb oyn citra perusahaan ketka m iliki tipgkat leverage yan tinggi dengan nelakukan pengungkapar lingk gan. Di) sisi lain, hasil negatif dito kan ole Diantimala \& Amri co Leve age by engaruh positif
signifik environmental disclosur

\section{Pengaruh Tipe Auditor Terhadap \\ Environmental Disclosure}

Kantor Akuntan Publik (KAP) terbesar di dunia dikenal dengan nama big four merupakan KAP yang memberikan jasa profesional yang sebagian besar menangani pekerjaan audit perusahaan swasta maupun publik. Pemilihan tipe auditor perusahaan akan berpengaruh terhadap pengungkapan lingkungan. Semakin baik pemilihan KAP maka tingkat kredibilitas laporan perusahaan akan semakin tinggi. Perusahaan yang memakai jasa dari KAP big four memberikan hasil audit yang relevan sesuai dengan kemampuan perusahaan daripada KAP non big four. Hal ini dilakukan sebagai upaya legitimasi perusahaan terhadap masyarakat. Auditor independen dari KAP big four akan meminta perusahaan untuk melakukan pengungkapan lingkungan. Temuan penelitian yang sejalan dengan penjelasan di atas terdapat pada Khalid et al., (2017) dan Wahyuningrum \& Pu-dihardjo (2018) yang menguji pen aruh auditor terhadap environment disclosur hasil menyatakan bo na dapat ngaruh positif signifi an antara tip uditg dengan environmenta dis sure. Welbec etal., (17) tid gk menemukan peng tipe aud or terhadap epvi pnme al disclos

14. Tipe aud or memiliki pengaruh positif signifikan
disclosure

\section{varub Women Director Terhadap}

Envirumental Disclosure

- Keberadaan women directors dengan segala kelebihannya dianggap dapat meningkatkan pengungkapan informasi yang bersifat sukarela termasuk environmental disclosure. Women directors dianggap dapat memberikan suasana kerja yang lebih baik, terlihat dari kemampuan bersosialisasi dewan wanita yang lebih baik daripada dewan laki-laki. Semakin banyak dewan women directors yang berada dalam jajaran eksekutif dapat melindungi kepentingan pemangku kepentingan dan menunjukkan peningkatan keterlibatan mereka dalam mengatasai masalah lingkungan Al-Qahtani \& Elgharbawy, (2020). Sejalan dengan feminist ethical theory, keragaman perspektif diantara anggota dewan berkaitan pada keputusan yang dibuat sehingga keputusan tersebut menjadi lebih efektif dan efisien. Hasil penelitian yang mendukung hal ini dilakukan oleh Tasya \& Cheisviyanny (2019) dan Oserogho (2020) yang menemukan bahwa women directors mempunyai pengaruh positif terhadap environmental disclosure. Sedangkan Akbas (2016) menemukan tidak terdapat 
pengaruh women directors terhadap environmental disclosure.

H5: Women directors memiliki pengaruh positif signifikan terhadap environmental disclosure

\section{Pengaruh Kepemilikan Manajerial \\ Terhadap Environmental Disclosure}

Manajemen bertanggungjawab untuk menyiapkan annual report kepada pemilik perusahaan dan stakeholders. Oleh karena hal ini, manajemen diharapkan mengungkapkan semua informasi yang relevan dalam annual report sebagai dasar untuk pengambilan keputusan yang efisien (Omoye \& Wilson-Oshilim, 2018). Kepemilikan manajerial dapat diartikan dimana manajer dan direksi perusahaan mempunyai suara yang dipersentasikan dalam bentuk saham dan opsi (Sari et al., 2018). Kepemilikan manajerial akan menentukan kebijakan dan pengambilan keputusan. Tingkat kepemilikan manajerial yang tinggi, akan mempengaruhi manajer untuk memberikan perhatian lebih kepa pemegang saham. Tingkat kinerj perusahaan yang produktif akan memberikan informasi yang rel ropada stakeholders. Teori agen mel atkan hubungan antara agen dan pr inal hubungan ini akan n zyebabkan konflik argumentasi antara pih manajed dan pemegang sahar Oleh sec 3 itu perring mempertahan an hubungan ong baik dengan para nega asaham, $\delta /$ samping itu manajer erusahal memberikan keput sail yang baik sesuai dengan tujea pery ahaan. b aasarkan hal ini, peneliti dengan penjelasan di atas dì ukan oleh Sari et al., (2018) yang menjela $\boldsymbol{n}$ adanya pengaruh positif kepemilikan manajerial dengan environmental disclosure. Sementara Junita \& Yulianto (2018) menunjukkan hasil tidak terdapat pengaruh antara kepemilikan manajerial dengan environmental disclosure.

H6: Kepemilikan manajerial memiliki pengaruh positif signifikan terhadap environmental disclosure

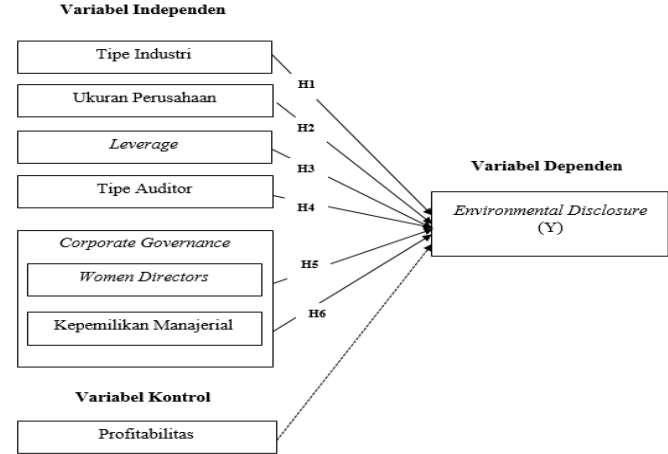

Gambar 1. Kerangka Pemikiran

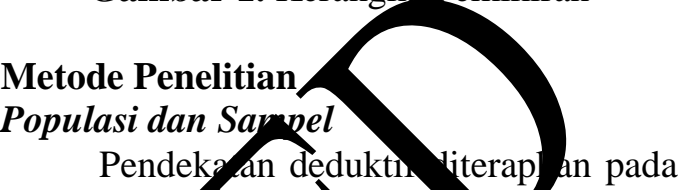
penelitian rengan peneh o / uantitatif sebaga savis elitiannya/ Studi ini meng rakan pop asi ya g berasal dari per ahao manufak ang tercatat pada c apore $\Delta$ hange (SGX) untuk periode 2017 - 2018 ng melakukan pelaporan informasi lingkungan pada annual report, sustainabilty report dan/atau ngungk pkan environmental disclosure padan site resmi.

Purposive sampling digunakan se agai metode pengambilan sampel, sebanyak 61 perusahaan sampel diperoleh sehingga menghasilkan sebanyak 122 unit analisis yang akan digunakan dalam penelitian. Teknik analisis yang digunakan yaitu analisis regresi linier berganda dengan menggunakan alat SPSS v21. Kriteria pengambilan sampel dijelaskan pada tabel 1

Tabel 1. Kriteria Pengambilan Sampel

\begin{tabular}{lc}
\hline \multicolumn{3}{c}{ Kriteria } & Jumlah \\
\hline Perusahaan manufaktur yang & 212 \\
listing di Singapore Exchange & \\
(SGX) periode 2017-2018 & \\
Perusahaan yang tidak & $(136)$ \\
melaporkan annual report \\
dan/atau sustainability report \\
Peusahaan yang mempunyai \\
data outlier \\
Jumlah perusahaan yang \\
dijadikan sampel penelitian \\
\hline $\begin{array}{l}\text { Sampel penelitian } \\
\text { Total unit analisis (61 x 2 th) }\end{array}$ \\
Sumber: Data sekunder yang telah diolah, 2020.
\end{tabular}




\section{Definisi Operasional Variabel}

Variabel dependen penelitian ini yaitu environmental disclosure, dengan variabel independen yang terdiri dari tipe industri, ukuran perusahaan, leverage, tipe auditor, women directors, kepemilikan manajerial dan variabel kontrol profitabilitas. Definisi operasional variabel dijelaskan pada tabel 2.

Tabel 2. Definisi Operasional Variabel

\begin{tabular}{|c|c|c|}
\hline Variabel & Definisi & Pengukuran \\
\hline Environmental & Pengungkapan informasi & Content Analysis (Wahyuningrum \\
\hline$(\mathrm{ED})$ & $\begin{array}{l}\text { lingkungan dalam laporan } \\
\text { bisnis }\end{array}$ & \& Budihardjo, 2018) \\
\hline Tipe Industri (TYPE) & $\begin{array}{l}\text { Penentuan tipe industri } \\
\text { berdasarkan high profile dan } \\
\text { low profile }\end{array}$ & $\begin{array}{l}\text { High proflle }=1 \\
\text { Low profile }=0 \\
\text { (Burgwal \& V }\end{array}$ \\
\hline Ukuran Perusahaan (SIZE) & $\begin{array}{l}\text { Ukuran besar kecilnya } \\
\text { perusahaan }\end{array}$ & hide ret \\
\hline Leverage (LEV) & $\begin{array}{l}\text { Kemampuan } \\
\text { dalam } \\
\text { kewajibannya }\end{array}$ & \\
\hline Tipe Auditor (AUD) & $\begin{array}{l}\text { Pemilihan } \\
\text { digunakan }\end{array}$ & $\begin{array}{l}0 \\
\text { hekwa, 2015) }\end{array}$ \\
\hline Women Directors (WOM) & $\begin{array}{l}\text { kom } \\
\text { peru }\end{array}$ & $\begin{array}{l}\frac{\text { ors }}{\text { irectors }} \\
\text { Hadipra }\end{array}$ \\
\hline $\begin{array}{l}\text { Kepemilikan Manajerial } \\
(\mathrm{OWN}) \\
\text { Profitabilitas (PROF) }\end{array}$ & & $\begin{array}{l}\text { Number of shares held by manager } \\
\text { Total shares } \\
\text { (Junita \& Yulianto, 2018) } \\
\text { Laba setelah bunga dan pajak } \\
\text { Total ekuitas } \\
\text { (Wahyuningrum \& Budihardjo, 2018) }\end{array}$ \\
\hline
\end{tabular}

Sumber: Penelitian crdahulu yang to diolah, 2020

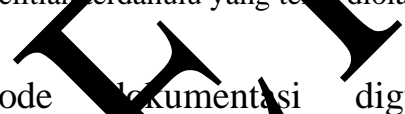

Metode rumentasi digunakan sebago - ode p gump ran data pada pep ian i. Tekn analisis statistik deskrip teknik analisis inferensial digunakan ebagar teknik analisis data. Teknik anah ystatistik inferensial yang digunakan teveri dari uji asumsi klasik, regresi linier berganda, uji hipotesis dan koefisien determinasi. Persamaan regresi berganda ditunjukkan pada persamaan 1 .

$\mathrm{ED}=\beta 0+\beta 1 \mathrm{TYPE}+\beta 2 \mathrm{SIZE}+\beta 3 \mathrm{LEV}+$ $\beta 4 \mathrm{AUD}+\beta 5 \mathrm{WOM}+\beta 6 \mathrm{OWN}+\beta \mathrm{PROF}+$ E.....................................(1)

\section{Hasil dan Pembahasan}

Environmental disclosure index (EDI) dari 122 unit analisis yang mencakup
8 tema pada environmental disclosure sesuai dengan GRI Standards 2016 dijelaskan pada tabel 3 .

Tabel 3. Statistik Deskriptif Total Skor EDI berdasarkan Kuantitas

\begin{tabular}{|c|c|c|c|c|c|}
\hline & $\mathbf{N}$ & Min & $\operatorname{Max}$ & Mean & $\begin{array}{l}\text { Std. } \\
\text { Dev }\end{array}$ \\
\hline Materials & 122 & 0 & 5 & 0.34 & 0.896 \\
\hline Energy & 122 & 0 & 13 & 2.77 & 2.653 \\
\hline Water & 122 & 0 & 5 & 0.93 & 1.533 \\
\hline Biodiversity & 122 & 0 & 6 & 0.15 & 0.789 \\
\hline Emissions & 122 & 0 & 9 & 1.38 & 2.344 \\
\hline $\begin{array}{l}\text { Effluents and } \\
\text { Waste }\end{array}$ & 122 & 0 & 8 & 1.19 & 1.829 \\
\hline $\begin{array}{l}\text { Environmental } \\
\text { Compliance }\end{array}$ & 122 & 0 & 3 & 1.11 & 1.112 \\
\hline $\begin{array}{l}\text { Supplier } \\
\text { Environmental } \\
\text { Assesment }\end{array}$ & 122 & 0 & 5 & 0.48 & 1.241 \\
\hline
\end{tabular}

Sumber: Data sekunder yang telah diolah, 2020. 
Berdasarkan Tabel 3. terdapat tema pengungkapan yang belum diungkapkan perusahaan. Hal ini diketahui dari nilai minimum sebesar 0 pada semua tema pengungkapan lingkungan. Tema energy dan emissions masing-masing menempati skor tertinggi pada posisi pertama dan kedua.

Nilai rata-rata energy sebesar 2.77 dengan standar deviasi 2.653 dan jumlah nilai maksimum 13. Nilai rata-rata yang diperoleh menunjukkan angka lebih besar dibandingkan dengan standar deviasi. Emissions memperoleh nilai rata-rata sebesar 1.38 dengan standar deviasi 2.344. Berdasarkan perolehan tersebut sebagian besar perusahaan melaporkan tema energy dan emissions dalam laporan laporan environmental disclosure. Hasil berbeda ditunjukkan oleh biodiversity yang merupakan posisi terakhir dari semua tema pengungkapan lingkungan dengan nilai standar deviasi 0.789 dan rata-rata sebesar 0.15 serta skor maksimum 6. Nilai tersebut memiliki perbandingan yang jauh dengan energy dan emissions.

Tabel 4. Hasil Statistik Deskriptif

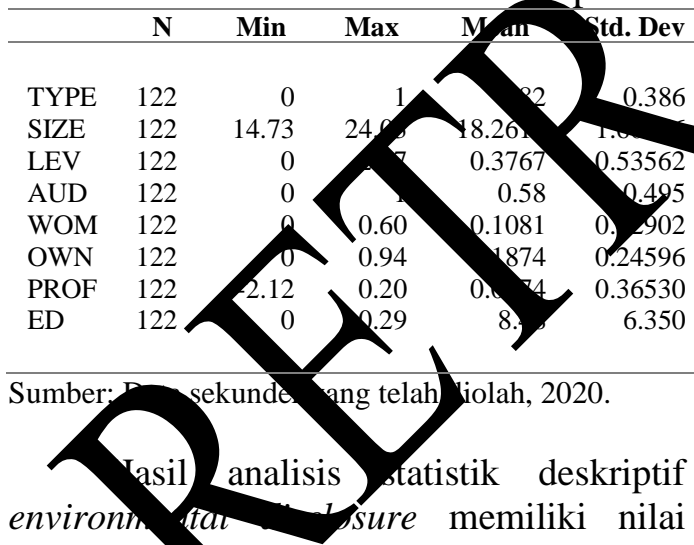

rata-rata o 8. Nilai rata-rata terendah dimiliki oleh diabel women directors dan profitabilitas dengan nilai berturut-turut sebesar 0.11 dan 0.09 . Nilai rata-rata yang dimiliki tipe industri, ukuran perusahaan, leverage, tipe auditor, dan kepemilikan manajerial berturut-turut sebesar 0.82, 18.26, 0.38, 0.58, dan 0,19. Asumsi klasik diuji dengan menggunakan empat pengujian yang terdiri dari uji normalitas, uji multikolinieritas, uji heterokedastisitas, dan uji autokorelasi.

Uji normalitas memakai uji OneSample Kolmogorov-Smirnov, hasil uji menemukan bahwa nilai signifikansi 0.895 . Hasil tersebut menunjukkan nilai signifikansi lebih besar dari tingkat kepercayaan $(\alpha=0.05)$, atas dasar hal tersebut data dalam penelitian ini terdistribusi secara normal. Uji multikolinieritas penelitian ini memperoleh nilai tolerance $>0.10$ dan nilai VIF $<10$, hal ini dapat diartikan bahwa model regresi penelitian tidak menunjukkan adanya multikolinieritas. Uji heterokedastisitas menggunakan Rank Spearman yang menunjukkan hasil bah asing-masing variabel memiliki sig ufikansi 0.05 . Uji autokorelasi mengga kan uji Run-test dengan nilai simfikan senilai $.083>$ 0.05, maka d a penglitian derhi dar dari gejala autakor si.

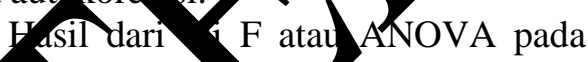
pene ito ini menu vkk nilai $F$ hitung 6,02. dan ilai sig. (enunjukkan angka 0,00Q. Oleh 1 rena nilai probabilitas lebih rendah daripadà $\% 5$, sehingga ED dapat diprediksi dengan menggunakan model gresi pa la penelitian ini, atau dapat d. ikan oahwa variabel TYPE, SIZE, LEV, AUD, WOM, OWN, dan PROF Ya simultan berpengaruh terhadap ED. Persamaan regresi berdasarkan regresi linier berganda terdapat pada Persamaan 2. dan hasil pengujian hipotesis dapat dilihat pada Tabel 5 .

$\mathrm{ED}=-3.610-0.099 \mathrm{TYPE}+1.218$ SIZE $+0.896 \mathrm{LEV}+0.520$ AUD $-0.425 \mathrm{WOM}$ $-0.105 \mathrm{OWN}+0.397 \mathrm{PROF}+\varepsilon$

Tabel 5. Hasil Simpulan Hipotesis

\begin{tabular}{|c|c|c|c|}
\hline Ket & B & Sig. & Keputusan \\
\hline $\mathrm{H}_{1}$ & -0.099 & 0.694 & Ditolak \\
\hline $\mathrm{H}_{2}$ & 1.218 & 0.034 & Diterima \\
\hline $\mathrm{H}_{3}$ & 0.896 & 0.001 & Diterima \\
\hline $\mathrm{H}_{4}$ & 0.520 & 0.011 & Diterima \\
\hline $\mathrm{H}_{5}$ & -0.425 & 0.301 & Ditolak \\
\hline $\mathrm{H}_{6}$ & -0.105 & 0.754 & Ditolak \\
\hline
\end{tabular}

Sumber: Data sekunder yang telah diolah, 2020

Hipotesis pertama (H1) membuktikan bahwa tidak terdapat pengaruh signifikan antara tipe industri terhadap environmental disclosure. Kondisi yang demikian tidak 
selaras dengan teori legitimasi yang mengemukakan bahwa perusahaan yang aktivitas produksinya bersinggungan dengan alam/lingkungan akan mendapatkan perhatian yang lebih oleh masyarakat, sehingga pengungkapan lingkungan dilakukan sebagai salah satu tindakan pertanggungjawaban perusahaan kepada masyarakat. Jenis perusahaan yang terklasifikasi dalam kategori high profile mendapatkan rasio yang lebih tinggi dibandingkan low profile. Akan tetapi, perusahaan high profile belum merespon lebih untuk melakukan pengungkapan lingkungan. Verawaty et al., (2020) menyatakan bahwa perusahaan yang termasuk high profile belum tentu melakukan pengungkapan sosial dibandingkan low profile. Artinya jenis industri bukan merupakan suatu faktor penentu bahwa perusahaan tersebut melakukan pengungkapan informasi lingkungan. Teori stakeholder yang menyatakan bahwa tekanan sosial dari para stakeholder akan meningkatkan pengungkapan lingkungan. Namun, pa prakteknya tekanan sosial yang diberika belum memberikan pengaruh yang besar terhadap perusahaan. Temua IIr elaras dengan hasil studi empiris alid $t$ al., (2017) dan Verawaty a Sementara pengaruh $\mathrm{p}$ tif ditemu $\mathrm{s}$ pada penelitian Wahyun gru \& Budh djo (2018) dan Baal at et al. (2 9).

Berdas kan hasil uj hipotesis, hipotesis keat ( $\mathrm{H}_{2}$ nenjelas an bahwa perusahaan bes yang terdaftar di Sing ore rxchan me ailiki pengaruh postl sign ikan ter cap environmental disclost won ukuran perusahaan dapat no vpengaruhi sejauh mana pelaporan linformasi lingkungan (Diantimala \& Amril, 2018). Ukuran perusahaan yang besar juga cenderung menjalankan kegiatan bisnis yang dapat menarik perhatian masyarakat. Teori legitimasi membenarkan pernyataan bahwa masyarakat akan memberikan tekanan sosial pada perusahaan besar daripada perusahaan kecil. Tekanan sosial menuntut perusahaan untuk memberikan tanggung jawab kepada masyarakat dengan melaporkan pengungkapan lingkungan. Baik perusahaan maupun masyarakat akan saling memberikan dampak positif jika masing-masing pihak dapat saling percaya. Beberapa penelitian menunjukkan hasil yang sama dengan penelitian ini seperti yang dilakukan Solikhah \& Winarsih (2015), Welbeck et al., (2017), Khalid et al., (2017), Diantimala \& Amril (2018), Junita \& Yulianto (2018) dan Nguyen et al., (2020).

Berdasarkan tabel 5. membuktikan bahwa leverage berpengaruh positif signifikan terhadap environmental disclosure, (H3) dito Tingginya tingkat leverage m mberikan pengaruh pada perusahaan ntuk m aporkan pengungkapan Angkan. n. Ba yaknya perusahaan ang pengga ungk in pada pembiayaan utar s, mo besar kecend ungan untuk melakukan peng ing apan lingk gan agar perusahaan dipa dang rebagai rusahaan berisiko renaxh (Elij -ten, 2004). Pengawasan yang dilakukan th pihak berkepentingan dilakukan terhadap perusahaan yang emiiki asio leverage yang tinggi. A.ungl pan lingkungan dilaporkan perusanaan dalam laporan tahunannya -gai bentuk pertanggungjawaban perusahaan dan untuk menjaga kepercayaan terhadap para stakeholder. Leverage memiliki pengaruh positif signifikan terhadap environmental disclosure ditemukan pada penelitian Yanto \& Muzzammil (2016) dan Hieu et al., (2019).

Hasil uji (H4) diterima, tipe auditor berpengaruh positif signifikan terhadap environmental disclosure. Sebanyak 58,2\% perusahaan yang dijadikan sampel pada penelitian ini menggunakan jasa auditor dari KAP big four. Pemilihan jenis tipe auditor ini akan berpengaruh terhadap pengungkapan lingkungan yang dilakukan perusahaan. Semakin baik kantor akuntan publik maka tingkat kredibilitas laporan perusahaan akan semakin tinggi. Hal ini merupakan upaya untuk meningkatkan kepercayaan masyarakat karena kualitas laporan yang dihasilkan perusahaan sesuai dengan standar yang berlaku. Menurut pandangan ini, pemilihan kantor akuntan publik merupakan merupakan faktor penting untuk mengoordinasikan kepentingan antara perusahaan dan pemangku kelompok kepentingan (Khalid 
et al., 2017). Oleh karena itu, pemilihan KAP big four termasuk keputusan yang tepat. Penelitian oleh Khalid et al., (2017), Wahyuningrum \& Budihardjo (2018) dan Alqatameen et al., (2020) membuktikan adanya pengaruh positif signifikan tipe auditor terhadap environmental disclosure .

Hipotesis kelima (H5) ditolak, women directors dalam struktur dewan diketahui tidak berpengaruh signifikan terhadap environmental disclosure. Sampel perusahaan yang digunakan pada penelitian ini cenderung menunjukkan proporsi direksi wanita yang rendah. Hal tersebut dapat dibuktikan dari keberadaan direksi wanita dalam suatu perusahaan berdasarkan annual report. Berdasarkan jumlah sampel penelitian sebanyak 122 unit analisis, sebanyak 57 unit analisis tidak terdapat direksi wanita dalam struktur dewan perusahaan. Sedangkan sisanya merupakan unit analisis yang memiliki proporsi dewan direksi wanita dalam perusahaan meskipun dengan jumlah yang relatif rendah. Tingkat keberadaan dewan direksi wanita yang rendah menunjukkan bahwa dewan dire masih didominasi oleh pria. Rendahny proporsi dewan direksi wanita menandakan bahwa kehadiran direksi w attro belum memberikan kontribusi dan eikut rtaan secara penuh dalam peng mkila re yang berkaitan der pn pengu kapan informasi lingkunga Ha penelitian oyg dilakukan Solik a \& W rih (2815), Fortunella \& Hadiprajitno ( 15) dan Akbas (2010) enup skan bahwa women directors tida memilki pengaruh signif Kan deng environmental discr. menyatakà bahwa tidak terdapat pengaruh yang signt an antara kepemilikan manajerial terhadap environmental disclosure. Struktur kepemilikan manajerial merupakan salah satu faktor yang dapat mempengaruhi efisiensi manajemen. Manajer puncak memiliki kekuatan untuk mengalokasikan sumber daya diantara pemangku kepentingan dengan cara memberikan dukungan dan memberikan tingkat insentif yang tinggi untuk mengurangi konflik agensi (Chang \& Zhang, 2015). Namun, hal tersebut berbanding terbalik dengan hasil penelitian ini. Rendahnya tingkat kepemilikan manajerial pada perusahaan di Singapura menimbulkan adanya ketidaksesuaian kebijakan. Junita \& Yulianto (2018) menyatakan tingkat kepemilikan manajerial yang rendah menyebabkan manajemen yang memiliki saham dalam suatu perusahaan belum dapat berperan aktif untuk dapat memberikan pemikiran terhadap keputusan yang diambil berkaitan dengan pengungkapan lingkungan. Junita \& Yulianto (2018) tidak menemukan adanya pengaruh kepemilikan marial terhadap environmental discloo re.

\section{Simpulan}

Pengur kapan ling unga pada perusahaan mo fak andi Sin pura tahun 2017-20,8 terg ong trasih rendah, mes po terjadi pen ngkatan pada pelaforan sustat, bility report. Berdosarkan sil uji hipotesis terdapat pengaruh posit signifikan yang teridiri dari ukurap perusahaan, leverage, dan tipe yditor terl adap environmental disclosure. S. entar itu, faktor-faktor lain seperti tipe industr1, women directors, dan kepemilikan - ajerial tidak menemukan adanya pengaruh yan signifikan. Perusahaan besar lebih diperhatikan oleh masyarakat karena kredibilitasnya, salah satu upaya menjaga kredibilitas dengan melakukan pengungkapan lingkungan. Tingkat leverage yang tinggi akan meningkatkan pengungkapan environmental disclosure sebagai upaya untuk menjaga kepercayaan stakeholder. Pemakaian jasa auditor dari KAP big four dapat mempengaruhi tingkat pengungkapan lingkungan, salah satu alasannya yaitu karena kualitas laporan yang diaudit memiliki kredibilitas dan kepercayaan yang tinggi dan menghimbau perusahaan untuk dapat melaporkan environmental disclosure dalam laporan tahunannya. Tekanan sosial pada perusahaan high profile belum memberikan dampak yang berarti untuk meningkatkan environmental disclosure. Rendahnya proporsi women directors dan kepemilikan manajerial belum memberikan kontribusi penuh bagi direktur wanita dan pihak manajer untuk ikut serta dalam pengambilan keputusan. 
Penelitian ini hanya berfokus pada perusahaan manufaktur sehingga data yang diperoleh hanya pada satu sektor. Jumlah sampel penelitian yaitu 61 perusahaan dengan periode pengamatan selama 2 tahun belum memberikan data yang komprehensif. Perusahaan yang mengungkapkan informasi environmental disclosure pada sustainability report masih sedikit meskipun telah diberlakukan mandatory disclosure.

Berdasarkan implikasi di atas saran yang dapat diberikan yaitu menambah jumlah sampel penelitian dengan memperpanjang periode pengamatan. Pengukuran women directors dapat diganti menggunakan variabel dummy agar mendapatkan hasil yang baik. Populasi penelitian tidak hanya difokuskan pada perusahaan di sektor industri, tetapi dapat diperluas pada semua sektor. Penambahan variabel lain seperti umur perusahaan, kinerja lingkungan, dan kepemilikan institusional yang diduga mempengaruhi environmental disclosure.

Berdasarkan simpulan dari ha penelitian saran yang dapat diberikan yait sebagian besar perusahaan yang tercatat di SGX melaporkan environment can losure sesuai dengan GRI Standane 2016, tetapi secara keseluruhan ting apela pengungkapan inform lingkunga cukup rendah. Oleh karc a h penting gi otoritas terten untuk memberkan peringatan at a mepbuat sua kgbijakan yang dapah ning axkan enveronmental disclosure Perus an bes lebih banyak meno ngk kan en ronm ntal disclosure dan ndery $\mathrm{g}$ meml, aset yang besar pula. Or kran peningkatan kualitas sumber do manusia dengan strategi perencanaan gaik dapat meningkatkan aset perusahaan. Sehingga, dengan adanya sumber keuangan yang cukup dapat melakukan pengungkapan lingkungan. Perusahaan dapat menggunakan jasa KAP big four untuk meningkatkan pelaporan environmental disclosure.

\section{Daftar Pustaka}

Akbas, H. E. (2016). The Relationship Between Board Characteristics and
Environmental Disclosure: Evidence From Turkish Listed Companies. South East European Journal of Economics and Business, 11(2), 7-19. https://doi.org/10.1515/jeb-2016-0007

Al-Qahtani, M., \& Elgharbawy, A. (2020). The effect of board diversity on disclosure and management of greenhouse gas information: evidence from the United Kingdom. Journal of Enterprise Information Management, 33(1557-1579).

https://doi.org/10.110IM-082019-0247

Alqatameen, D. A., d, M., A balaileh, A., \& Dadoghia, M. N. (2020). Owners ip Structum, Board Comosh on and Noluntary D. closure \& Non- inancial firms In SE International Bustim r Resean , 13(7), 93-107. https://a org/10.5539/ibr.v13n7p93

Baalouch, F., \& hak, S., \& Khaled, A. (2019). A Study of The Determinants of En ironmental Disclosure Quality: Evid nce From French Listed Companies. In Journal of Management and Governance (Vol. 23, Issue 4). Springer US. https://doi.org/10.1007/s10997-01909474-0

Benlemlih, M., Shaukat, A., Qiu, Y., \& Trojanowski, G. (2018). Environmental and Social Disclosures and Firm Risk. Journal of Business Ethics, 152(3), 613-626. https://doi.org/10.1007/s10551-0163285-5

Burgwal, D. Van De, \& Vieira, R. J. O. (2014). Environmental Disclosure Determinants in Dutch Listed Companies. Revista Contabilidade \& Finanças - USP, 25(64), 60-78.

Burlea Schiopoiu, A., \& Popa, I. (2013). Legitimacy Theory. In Ensyclopedia of Corporate Social Responsibilty (pp. 1579-1584).

https://doi.org/10.1007/978-3-64228036-8_471

Chang, K., \& Zhang, L. (2015). The Effects of Corporate Ownership Structure on Environmental Information Disclosure - Empirical Evidence from Unbalanced Penal Data in Heavy- 
pollution Industries in China. WSEAS Transactions on Systems and Control, 10(1996), 405-414.

Council For Board Diversity. (2020). With more companies appointing women to their boards, those with few or no women on boards need to take decisive action: Council for Board Diversity. Diakses pada 20 Januari 2021.

https://www.councilforboarddiversity. sg/wp-content/uploads/2020/03/202003-17-CBD-NewsRel-Morecompanies-appointing-women-totheir-boards.pdf

Dewi, I. A. P. O., \& Yasa, G. W. (2017). Pengaruh Ukuran Perusahaan, Profitabilitas, Tipe Industri dan Kinerja Lingkungan Terhadap Environmental Disclosure. E-Journal Akuntansi Universitas Udayana, 20(3), 2362-2391.

Diantimala, Y., \& Amril, T. A. (2018). The Effect of Ownership Structure, Financial and Environmental Performances on Environmen Disclosure. Accounting Analys Journal, 7(1), 70-77. https://doi.org/10.15294/2 2001

Dibia, N. O., \& Onwuc

Determinants

Disclosures in ige A Case dy of Oil and Gas Companies. Internat nal Jpurnal of $\mathbf{A}$ ance and Accolnth $\quad$ (3), /45-152. httns://doi.o 10.5923 i.ijfa. 2015040

Dyau J. (017). Fin cial Environmental DN sum the Annual Reports of Listed Companies in Poland. Internat al Journal of Trade, Economtcs and Finance, 8(3), 169174.

https://doi.org/10.18178/ijtef.2017.8.3 .557

Elijido-ten, E. (2004). Determinants of Environmental Disclosures in a Developing Country: an Application of The Stakeholder Theory. Fourth Asia Pacific Interdisciplinary Research in Accounting Conference, $1-28$.

Fortunella, A. P., \& Hadiprajitno, B.
(2015). The Effects of Corporate Governance Structure and Firm Characteristic Towards Environmental Disclosure. Diponegoro Journal of Accounting, 4(2), 1-11.

Ghozali, I., \& Chariri, A. (2007). Teori Akuntansi. Semarang: Badan Penerbit Universitas Diponegoro Semarang.

Hadiningtyas, S. W., \& Mahmud, A. (2017). Environmental Disclosure on Companies Listed in Indonesia Stock Exchange (IDX). Accounting Analysis Journal, 6(3), 380

Hieu, P. D., Thuy, L . T., Ng H. T. B., \& Lam, N. Th (2019). A ndatory Social and Akviron ental D closure of Lis d Companic in ietnam. Academy Aconting \& Financial St dies Jou , $1,23(5)$

Junit L., \& Y. nnte A. (2018). The Deter inants Affecting Environ ntal Disclosure in the High Profile 9 panies in Indonesia. Accoynting Analysis Journal, 7(3), 114- 50.

httn//doi.org/10.15294/aaj.v7i3.1841 hid, T. B., Kouhy, R., \& Hassan, A. (2017). The Impact of Corporate Characteristics on Social and Environmental Disclosure (CSED): The Case of Jordan. Journal of Accounting and Auditing: Research \& Practice, 2017, 1-29. https://doi.org/10.5171/2017.369352

Loh, L., \& Tang, M. (2019). Sustainability Reporting - Progress and Challenges. Centre For Governance, Institutions \& Organizations NUS Business School.

Loh, L., \& Thomas, T. (2018). Sustainability Reporting In ASEAN Countries. ASEAN CSR Network. https://www.asean-csrnetwork.org/c/images/Resources/Repo rts/2018_Sustainability_Reporting_in _ASEAN_Countries.pdf

Lu, L. W., \& Taylor, M. E. (2018). A study of the relationships among environmental performance, environmental disclosure, and financial performance. Asian Review of Accounting, 26(1), 107-130. https://doi.org/10.1108/ARA-012016-0010 
Mousa, G. A., \& Hassan, N. T. (2015). Legitimacy Theory and Environmental Practices : Short Notes Legitimacy Theory and Environmental Practices : Short Notes. International Journal of Business and Statistical Analysis, 2(1). https://doi.org/10.12785/ijbsa/020104

Nguyen, T. L. H., Nguyen, T. T. H., Nguyen, T. T. H., Le, T. H. A., \& Nguyen, V. C. (2020). The Determinants of Environmental Information Disclosure in Vietnam Listed Companies. Journal of Asian Finance, Economics and Business, 7(2), 21-31. https://doi.org/10.13106/jafeb.2020.vo 17.no2.21

Ningtyas, A. A., \& Triyanto, D. N. (2019). Pengaruh Kinerja Lingkungan dan Pengungkapan Lingkungan Terhadap Profitabilitas Perusahaan. Jurnal Akuntansi, Audit Dan Sistem Informasi Akuntansi, 3(1), 14-26.

Nugraha, D. E. B., \& Juliarto, A. (2015). Pengaruh Ukuran Perusahaan, TH Industri, Profitabilitas, Leverage, da Kinerja Lingkungan Terhadap Environmental Disclos re Studid Emipiris Pada Peran yaan yang Terdaftar di BEI do Nen, $\mathrm{li}$. PROPER TP 201 2013). Diponegoro Jurna of Accou ing, 4(2014),

Ohidoa, T. Omokhudu, O. O., \& Oserogho I A. F) (2016). Determinan of Environmental ISCh ure. In rnati hal Journal of vean ed Acade, C Research, 2(8),

Omoye, A S., \& Wilson-Oshilim, U. D. (2018). Yecedents of Environmental Disclosure in Nigeria. Accounting \& Taxation Review, 2(2), 101-116.

Oserogho, I. A. F. (2020). Extent Of Environmental Disclosure of Listed Non-Financial Firms in Nigeria: Does Board Characteristics Matter? Ilorin Journal of Human Resource Management, 4(1), 215-226.

PUB. (2019). Companies Prosecuted for Illegal Discharge into Public Sewers between June 2018 and May 2019. PUB Singapore's National Water
Agency. Diakses pada 18 Januari 2021.

https://www.pub.gov.sg/sites/assets/Pr essReleaseDocuments/38 Companies Punished for Illegal Discharge into Public Sewers (10 Jun 2019)_Annex A.pdf

Sari, G. A. C. N., Yuniarta, G. A., \& Wahyuni, M. A. (2018). Pengaruh Mekanisme Good Corporate Governance, Profitabilitas, dan Kinerja Lingkungan Terhadap Environmental Diso (Studi pada Perusahaan Sek r Pertan ngan dan Sektor Perkeban yang To aftar di BEI dan. Juxnal wiah A intansi, 9(3), $14-155$.

Singapore a ban . (20) SGX-ST Li ang Ru Pracice Note 7.6 ot. vinability Re orting Guide. Diak. pada -5 Maret 2020. http://ru, book.sgx.com/rulebook/prac tice-note- $\lambda$ sustainability-reportingguide

olikhah, 及., \& Winarsih, A. M. (2015). Pen aruh Media, Sensitivitas Industri dan Struktur Corporate Governance Terhadap Kualitas Environmental Disclosure (Studi Pada Perusahaan High Profile di Bursa Efek Indonesia Periode 2011-2013). Accounting Analysis Journal, 4(2), 1-9. https://doi.org/https://doi.org/10.1529 4/aaj.v4i2.7758

Tasya, N. D., \& Cheisviyanny, C. (2019). Pengaruh Slack Resources dan Gender Dewan Terhadap Kualitas Pengungkapan Tanggung Jawab Sosial Perusahaan (Studi Emipiris Perusahaan yang Menerbitkan Laporan Keberlanjutan dan Terdaftar diBursa Efek Indonesia Tahun 20152017). Jurnal Eksplorasi Akuntansi, 1(3), 1033-1050.

TSE. (2018). Japan's Corporate Governance Code. Diakses pada 25 April 2020. https://www.jpx.co.jp/english/news/10 20/b5b4pj000000jvxratt/20180602_en.pdf

Verawaty, Merina, C. I., Jaya, A. K., \& Widianingsih, Y. (2020). Determinants of Environmental Disclosure in Indonesia. Advances in 
Economics, Business and Management Research, 117, 217-226. Wahyuningrum, I. F. S., \& Budihardjo, M. A. (2018). Relationship between Company Financial Performance, Characteristic and Environmental Disclosure of ASX Listed Companies. E3S Web of Conference 73, 24, 3-7. https://doi.org/10.1051/e3sconf/20187 310024

Welbeck, E. E., Owusu, G. M. Y., Bekoe, R. A., \& Kusi, J. A. (2017). Determinants of Environmental Disclosures of Listed Firms in Ghana. International Journal of Corporate Social Responsibility, 2(1), 11. https://doi.org/10.1186/s40991-0170023-y

Wicks, A. C., Gilbert, D. R., \& Freeman, R. E. (1994). A Feminist Reinterpretation of The Stakeholder Concept. Business Ethics Quarterly, 4(4), 475-497. https://doi.org/10.2307/3857345

Yanto, H., \& Muzzammil, B. S. (2016). A Long Way to Implement Environmental Reporting in Indonesian Mining Companies. International Journal of Applied Business and Ec Research, 14(10), 93-6513. https://doi.orgho 139/ssrn._ 08974

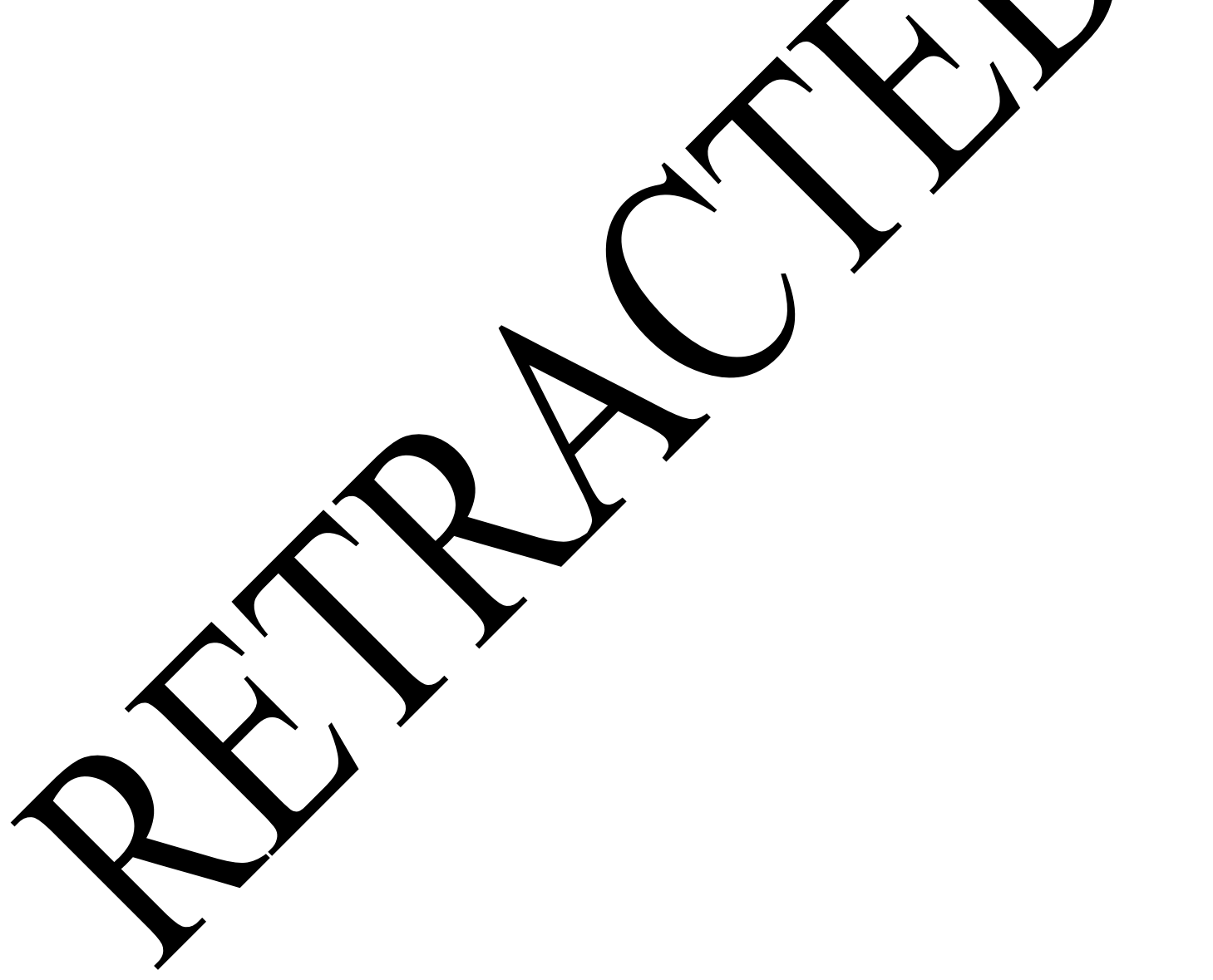

